\title{
POTENSI EKSTRAK DAUN KELOR (Moringa Oleifera) SEBAGAI HEPATOPROTEKTOR PADA TIKUS PUTIH (Rattus Novergicus) YANG DIINDUKSI PARASETAMOL DOSIS TOKSIS
}

\author{
Noer Kumala I. ${ }^{1}$, Masfufatun ${ }^{1}$, Emilia Devi D.R. ${ }^{2}$ \\ ${ }^{1}$ Bagian Biokimia Fakultas Kedokteran \\ ${ }^{2}$ Bagian Biomedik Fakultas Kedokteran \\ Universitas Wijaya Kususma Surabaya \\ Email: azamkumala@gmail.com
}

\begin{abstract}
Abstrak
Tanaman Kelor (Moringa oleifera) merupakan tanaman yang mengandung senyawa-senyawa kimia yang bermanfaat, diantaranya adalah senyawa flavonoid. Kemampuan senyawa flavonoid dapat menangkap radikal bebas penyebab kerusakan hepar.

Tujuan Penelitian mengetahui kadar ekstrak daun Kelor dan sejauh mana ekstrak daun kelor dapat mengatasi efek kerusakan hepar yang ditimbulkan oleh parasetamol dosis toksis melalui kadar MDA, SGOT, dan SGPT.

Metode yang digunakan dalam penelitian eksperimental laboratorik ini adalah Randomized Post Test Only Control Grup Design dengan tahapan sebagai berikut:1. Ekstraksi Daun Kelor dengan Etanol 96\%; 2.Preparasi hewan Coba,3. Perlakuan terhadap Hewan Coba dengan pemberian ekstrak Daun Kelor 3 dosis yaitu: 250mg/200BB tikus(dosis A), 500mg/200BB tikus(dosis B), $1000 \mathrm{mg} / 200 \mathrm{BB}$ tikus(dosis C) selama 14 hari dikombinasi dengan parasetamol $2 \mathrm{gr} / 200 \mathrm{BB}$ tikus, yang dibandingkan dengan kelompok kontrol negatif (kelompok yang hanya diberi parasetamol 2gr/200BB tikus) dan kelompok kontrol positif (kelompok yang hanya diberi pakan biasa) selama 14 hari.

Hasil yang diperoleh ternyata ada perbedaan yaitu penurunan kadar SGOT secara signifikan secara statistik antara kelompok kontrol negatif dengan kelompok perlakuan dosis tinggi yaitu dosis $C$ dengan $\alpha=0,016$ yang lebih kecil dari 0,05 , sedangkan penurunan kadar SGPT secara signifikan juga mengalami penurunan pada kelompok perlakuan dosis tinggi yaitu dosis $\mathrm{C}$ dengan $\alpha=0,009$ yang lebih kecil dari 0,05. Sedangkan kadar MDA kelompok perlakuan dengan kelompok kontrol negatif mengalami penurunan secara keseluruhan untuk dosis A dengan $\alpha=$ 0,05 , dosis B dengan $\alpha=0,011$ sedang dosis $C$ dengan $\alpha=0,001$.

Kesimpulan pada penelitian ini ekstrak Daun kelor dapat berpotensi sebagai antioksidan pada semua dosis sekaligus dapat sebagai hepatoprotektor pada dosis tinggi yaitu $1000 \mathrm{mg} / 200 \mathrm{BB}$ tikus.
\end{abstract}

Kata Kunci : ekstrak daun Kelor, hepatoprotektor

\section{POTENTIAL EXTRACT OF Moringa Oleifera AS HEPATOPROTECTIVE IN WHITE RATS (Rattus novergicus) INDUCED TOXIC DOSES OF PARACETAMOL}

\begin{abstract}
Moringa Oleifera is a plant that contains chemical compounds that are useful, such as flavonoids. The ability of this flavonoid compound that can capture free radicals cause damage and hepatoprotektan hepar.

Purpose of study was to determined levels of Moringa leaf extract which can overcome the effects of liver damage caused by toxic doses of paracetamol through MDA, SGOT and SGPT

Method used in this laboratory experimental study is a Randomized Post Test Only Control Group Design with the following stages: 1. Moringa Leaf Extraction with Ethanol 96\%; Try 2.Preparasi animals, 3. Treatment of Animals Try the extract of leaves of Moringa 3 dose is: 250mg / 200BB rat (dose of A), 500mg / 200BB mice (dose B), 1000mg / 200BB mice (dose C) for 14 days in combination with paracetamol $2 \mathrm{~g} / 200 B B$ mice, compared to the negative control group (group given just paracetamol $2 \mathrm{~g} / 200 \mathrm{BB}$ rat) and the positive control group (the group who were given regular feed) for 14 days.
\end{abstract}


Results : turned out to be no difference in the reduction in SGOT levels are statistically significant between the negative control group with high-dose treatment group ie the dose $C$ with $\alpha=0,016$ smaller than 0.05, whereas a decrease in ALT levels were significantly decreased in the treatment group high dose is the dose $C$ with $\alpha=0,009$ smaller than 0.05. While MDA group treated with the negative control group experienced an overall decline for the dose $A$ with $\alpha=0,05$, dose $B$ with $\alpha=0,0011$ and dose $C$ with $\alpha=0,001$.

Conclusion of this study showed that the extract of Moringa leaves can be potentially as an antioxidant in all doses at once can be as hepatoprotektor at high doses is 1000mg / 200BB Rattus Novergicus.

Keywords : Moringa oleifera extract, hepatoprotective

\section{PENDAHULUAN}

Parasetamol yang digunakan secara berlebihan/ melebihi dosis dapat mengakibatkan kerusakan hati. Kerusakan hepar oleh parasetamol secara berlebihan diakibatkan karena terbentuknya metabolit reaktif toksik (N-asetil-p-benzoquinon) dan radikal bebas melalui proses biotransformasi oleh enzim sitokrom P450 dengan bantuan isoenzim CYP2EI. Metabolit reaktif toksik dan radikal bebas dapat mengganggu integritas membran sel, berlanjut menjadi kerusakan hepar selanjutnya gagal ginjal ${ }^{1}$.

Peningkatan enzim-enzim transaminase dalam serum yang terdiri dari Aspartate Amino Transaminase / Glutamate Oxaloacetate Tansaminase (AST/GOT) dan Alanine Amino

\section{Transferase / Glutamate Pyruvate} Transaminase (ALT/GPT) merupakan penanda dini yang lebih spesifik untuk deteksi kerusakan hepar ${ }^{2}$. Salah satu mekanisme yang berperan terhadap kerusakan hepar adalah penumpukan radikal bebas. Radikal bebas yang berlebihan akan menimbulkan stres oksidatif yang memicu proses peroksidasi terhadap lipid, sehingga menimbulkan penyakit kanker, inflamasi, ateroklerosis, dan mempercepat proses penuaan ${ }^{3}$. Senyawa yang menjadi penanda terjadinya stress oksidatif adalah Malondialdehiyd (MDA). MDA merupakan produk oksidasi asam lemak tidak jenuh oleh radikal bebas serta metabolit komponen sel yang dihasilkan oleh radikal bebas. Tingginya kadar MDA menunjukkan proses oksidasi dalam membran sel, bila antioksidan tinggi biasanya diikuti oleh penurunan kadar MDA ${ }^{4}$.

Salah satu upaya menghindari efek samping pemberian parasetamol dosis toksis yaitu engan cara memberikan hepatoprotektan. Salah satu sumber pangan yang berfungsi sebagai hepatoprotektor adalah ektrak daun kelor. Daun Kelor merupakan tanaman yang mengandung senyawa-senyawa kimia yang bermanfaat, diantaranya adalah senyawa flavonoid. Kemampuan senyawa flavonoid inilah yang dapat menangkap radikal bebas penyebab kerusakan hepar ${ }^{5}$.

Sehingga peneliti tertarik untuk mengetahui sejauh mana potensi pemberian ekstrak daun kelor (Moringa Oleifera) sebagai antioksidan dan hepatoprotektor pada tikus putih (Rattus novergicus) yang dipapar dengan parasetamol dosis toksis melalui kadar MDA,SGOT dan SGPT

Tujuan penelitian ini adalahMengetahui potensi ekstrak daun kelor (Moringa Oleifera) sebagai antioksidan melalui kadar Malondialdehyd (MDA) dan hepatoprotektor melalui kadar SGOT dan SGPT pada tikus putih (Rattus novergicus) yang dipapar dengan parasetamol dosis toksis. 


\section{BAHAN DAN METODA}

Bahan Penelitian:

Ekstrak Daun Kelor, etanol 96\% aquades, parasetamol, pakan tikus 511, reagen SGPT dan SGOT, larutan PBS, larutan TCA 15\%, Larutan TBA 0,37\%.

\section{Preparasi Hewan Coba}

Hewan Coba tikus putih galur wistar sebanyak 25 ekor dengan berat 200-300 gram. Hewan coba yang terkumpul diadaptasi selama satu minggu (diberi pakan biasa dan aquadest).Hewan coba yang telah diadaptasi satu minggu dikelompokkan secara acak menjadi 5 kelompok.

\section{Preparasi daun kelor}

Ekstraksi Etanol Daun Kelor : Daun Kelor dicuci dan dikeringkan 2-4 hari, lalu diblender. Kemudian dihaluskan dan ditimbang $1 \mathrm{~kg}$ dimaserasi dengan etanol $70 \%$ selama 24 jam dan disaring. Rresidu dimaserasi lagi sampai filtrat jernih. Filtrat/maserat dikumpulkan jadi satu, dipekatkan dengan vacuum evaporator (suhu $30-40^{\circ} \mathrm{C}$, tekanan $75 \mathrm{mmHg}$ ).

\section{Perlakuan terhadap hewan coba}

a. Kelompok $\mathrm{K}$ hanya diberi pakan biasa dan aquadest selama 14 hari

b. Kelompok K(-)diberi aquadest selama 10 hari+ parasetamol 2gr/200BB tikus pada hari ke 7

c. Kelompok A diberi ekstrak etanol daun kelor 250mg/200BB tikus selama 14 hari+parasetamol 2gr/200BBtikus pada hari ke 7

d. Kelompok B diberi ekstrak etanol daun kelor 500mg/200BBtikus selama 14 hari+parasetamol 2gr/200BBtikus pada hari ke 7

e. Kelompok $\mathrm{C}$ diberi ekstrak etanol daun kelor $1000 \mathrm{mg} / 200 \mathrm{BB}$ tikus selama 14 hari+parasetamol 2gr/200BBtikus pada hari ke 7

\section{Pengambilan darah hewan coba}

Pengambilan darah hewan coba pada semua kelompok dengan menggunakan spuit melalui jantung.

\section{Uji Kadar SGPT}

Pada masing-masing perlakuan : Dipipet $3 \mathrm{~mL}$ reagen SGPT $+0,3 \mathrm{~mL}$ serum dicampur dengan vortex kemudian dibaca absobansinya $\left(\lambda=340\right.$ dan suhu $37^{\circ} \mathrm{C}$.

\section{Uji kadar SGOT}

Pada masing-masing perlakuan : Dipipet $3 \mathrm{~mL}$ reagen $\mathrm{SGOT}+0,3 \mathrm{~mL}$ serum dicampur dengan vortex kemudian dibaca absobansinya $\left(\lambda=340\right.$ dan suhu $37^{\circ} \mathrm{C}$.

\section{Uji Kadar MDA}

1) $1 \mathrm{~mL}$ plasma sampel+ $1 \mathrm{mLTCA} 20 \%$ dingin, dicampur, disentrifuge 10 menit(3000 rpm)

2) Diambil $1 \mathrm{~mL}$ supernatant+ $2 \mathrm{~mL}$ TBA $0,67 \%$, dicampur

3) dimasukkan ke penangas mendidih selama \pm 15 menit sampai terbentuk warna merah muda, didinginkan

4) Baca serapan dengan $\lambda=532 \mathrm{~nm}$

\section{HASIL DAN PEMBAHASAN \\ HASIL PREPARASI DAUN KELOR}

Daun Kelor yang telah dicuci, dikeringkan dengan cara diangin-anginkan selama 2-4 hari untuk menghindari rusaknya kandungan flavonoid yang ada didalam daun kelor. Untuk mendapatkan hasil yang benarbenar kering ternyata membutuhkan waktu 5 hari. Dari proses preparasi daun Kelor didapatkan hasil bahwa $3 \mathrm{~kg}$ daun kelor basah menghasilkan $1 \mathrm{~kg}$ daun kelor yang benarbenar kering.

\section{HASIL PROSES MASERASI SERBUK DAUN KELOR}

Pada proses maserasi daun kelor yang telah dihaluskan digunakan etanol $96 \%$ bukan 
$70 \%$ dikarenakan alat evaporatornya tidak memiliki pompa, sehingga jika menggunakan alkohol 70\%, proses penguapannya lama, kemudian didiamkan selama 24 jam kemudian disaring, residu dimaseari lagi sampai fliltrat jernih dan ini membutuhkan 5 kali proses penyaringan, lalu filtrate dijadikan satu dan dimasukkan alat evaporator untuk dipekatkan dengan vacuum evaporator selama 10 jam $^{6}$.

Hasil daun kelor beker I dengan berat kering 438 gram dan daun kelor beker II dengan berat kering 327 gram, setelah dimaserasi 5 hari, semua filtrate dijadikan satu dan dipekatkan evaporator selama 10 jam dan diuapkan dengan alat inkubator untuk menguapkan airnya sampai kental selama 7 hari, maka dihasilkan ekstrak kental daun kelor sebesar 113 gram yang untuk selanjutnya akan dibuat larutan induk ekstrak etanol daun kelor.

Tabel 1. Hasi Berat Ekstrak Daun Kelor Hasil Inkubasi

\begin{tabular}{|c|l|l|l|}
\hline Berat Daun & Berat & Volume \\
Kelor Basah & $\begin{array}{l}\text { Serbuk } \\
\text { Daun Kelor }\end{array}$ & $\begin{array}{l}\text { Berat Filtrat } \\
\text { Ekstrak } \\
\text { Daun Kelor }\end{array}$ & $\begin{array}{l}\text { Ekstrak } \\
\text { Daun Kelor }\end{array}$ \\
\hline $3 \mathrm{Kg}$ & 763 gram & $3.950 \mathrm{~mL}$ & 113 gram \\
\hline
\end{tabular}

\section{HASIL PREPARASI HEWAN COBA}

Tikus putih sebanyak 30 ekor pada perjalanan perlakuan ada yang mati sehingga peneliti mengambil 25 ekor dan dikelompokkan menjadi 5 kelompok dilabeli dan diadaptasi selama 7 hari dengan pakan standar dan minum. Kelompok Perlakuan dosis ekstrak Kelor A yaitu dosis rendah (250mg/200BB tikus), Kelompok Perlakuan dosis ekstrak Kelor B yaitu dosis sedang (500mg/200BB tikus), Kelompok Perlakuan dosis ekstrak Kelor C yaitu dosis tinggi (1000mg/200BB tikus), Kelompok Kontrol Positif yaitu kelompok yang hanya diberi pakan standar selama 14 hari, Kelompok Kontrol Negatif yaitu kelompok yang hanya diberi parasetamol dosis toksis 5 ekor.

Setelah masa adaptasi selama 7 hari, maka dilakukan penimbangan berat badan yang digunakan sebagai acuan untuk menghitung dosis pemberian perlakuan pada tikus selama penelitian sebagaimana terlihat pada Tabel 2. Pemberian dosis parasetamol diberikan pada semua kelompok kecuali kelompok E yaitu kelompok kontrol positif.

Setelah hari ke 21, pada semua kelompok tikus dilakukan terminasi dengan pengambilan darah melalui jantung, tikus yang telah mati dikubur secara layak. Kemudian darah tikus dibuat serum untuk diukur kadar SGOT (Serum Glutamate Oxaloacetate Tansaminase) dan SGPT (Serum Glutamate Pyruvate Transaminase) untuk mengetahui potensi ekstrak daun kelor sebagai hepatoprotektor serta diukur kadar MDA (Malondialdehyd) untuk mengetahui potensi antioksidan dari ekstrak daun kelor. 
Tabel 2. Hasil Penimbangan Berat Badan Tikus Setelah Adaptasi 7 Hari dan Ekstrak Daun Kelor dengan 3 Dosis

\begin{tabular}{|c|c|c|c|c|c|c|c|}
\hline $\begin{array}{l}\text { Kelompok } \\
\text { (DOSIS) }\end{array}$ & Simbol & $\begin{array}{c}\text { BB } \\
\text { (Gram) }\end{array}$ & $\begin{array}{c}\text { Massa } \\
\text { Ekstrak } \\
\text { (gr) }\end{array}$ & $\begin{array}{c}\text { Volume } \\
\text { (mL) }\end{array}$ & SGOT (U/L) & SGPT (U/L) & $\begin{array}{c}\text { KADAR } \\
\text { MDA } \\
(\mathrm{mmol} / \mathrm{mL})\end{array}$ \\
\hline $\begin{array}{c}\mathrm{A} \\
(0,25 \mathrm{gr} / 200 \\
\mathrm{BB})\end{array}$ & A1 & 139 & 0.17375 & 1.39 & 154 & 146 & 10.10 \\
\hline & $\mathrm{A} 2$ & 117 & 0.14625 & 1.17 & 151 & 117 & 11.55 \\
\hline & A3 & 163 & 0.20375 & 1.63 & 270 & 116 & 9.38 \\
\hline & A4 & 145 & 0.18125 & 1.45 & 108 & 138 & 11.55 \\
\hline & A5 & 132 & 0.165 & 1.32 & 187 & 127 & 12.27 \\
\hline $\begin{array}{c}\mathrm{B}(0,50 \\
\mathrm{gr} / 200 \mathrm{BB})\end{array}$ & $\mathrm{B} 1$ & 166 & 0.415 & 1.66 & 108 & 163 & 11.55 \\
\hline & $\mathrm{B} 2$ & 149 & 0.3725 & 1.49 & 307 & 126 & 10.83 \\
\hline & B3 & 131 & 0.3275 & 1.31 & 189 & 119 & 11.55 \\
\hline & B4 & 136 & 0.34 & 1.36 & 180 & 129 & 10.83 \\
\hline & B5 & 117 & 0.2925 & 1.17 & 154 & 141 & 10.10 \\
\hline $\begin{array}{c}\mathrm{C}(1 \mathrm{gr} / 200 \\
\mathrm{BB})\end{array}$ & $\mathrm{C} 1$ & 136 & 0.68 & 1.36 & 110 & 109 & 9.38 \\
\hline & $\mathrm{C} 2$ & 116 & 0.58 & 1.16 & 87 & 94 & 8.66 \\
\hline & $\mathrm{C} 3$ & 184 & 0.92 & 1.84 & 174 & 84 & 7.94 \\
\hline & $\mathrm{C} 4$ & 114 & 0.57 & 1.14 & 100 & 82 & 9.38 \\
\hline & $\mathrm{C} 5$ & 139 & 0.695 & 1.39 & 117 & 112 & 9.38 \\
\hline $\mathrm{D}$ & D1 & 134 & \multirow{5}{*}{\multicolumn{2}{|c|}{$\begin{array}{l}\text { KONTROL } \\
\text { NEGATIF }\end{array}$}} & 268 & 153 & 12.27 \\
\hline & D2 & 133 & & & 283 & 209 & 12.27 \\
\hline & D3 & 140 & & & 307 & 143 & 13.00 \\
\hline & D4 & 149 & & & 205 & 138 & 12.27 \\
\hline & D5 & 123 & & & 133 & 154 & 13.00 \\
\hline $\mathrm{E}$ & E1 & 164 & \multirow{5}{*}{\multicolumn{2}{|c|}{ KONTROL POSITIF }} & 117 & 121 & 10.83 \\
\hline & E2 & 139 & & & 170 & 123 & 10.83 \\
\hline & E3 & 82 & & & 182 & 109 & 10.83 \\
\hline & E4 & 124 & & & 103 & 132 & 11.55 \\
\hline & E5 & 139 & & & 103 & 112 & 10.54 \\
\hline
\end{tabular}

\section{Uji Pengaruh Pemberian Ekstrak Daun}

Kelor terhadap kadar SGOT,SGPT dan kadar MDA pada Tikus Putih yang diinduksi Parasetamol Dosis Toksik

Indikator utama yang diamati terhadap adanya gangguan fungsi hati adalah aktifitas enzim tranaminase yang meliputi

ALT

(Alanin

aminotransferasease) atau SGOT (Serum

Glutamic Oxaloacetic Transaminase) dan AST (Aspartat aminotransferase) atau SGPT (Serum Glutamic Pyruvic Transaminase). Enzim Transaminase merupakan enzim intraselular, Jika terjadi kerusakan sel seperti gangguan permeabilitas dinding sel hati akibat suatu gangguan, maka aktivitasnya akan meningkat ${ }^{7}$. Peningkatan aktivitas SGOT dan SGPT dapat diakibatkan karena pemberian dosis parasetamol yang berlebihan.

Adanya parasetamol yang dikonsumsi secara berlebihan menstimulasi sitokrom P450 dan memicu radikal bebas. Radikal bebas berupa metabolit reaktif $n$ asetil p- benzokuinonomin (NAPQ1) yang akan mengoksidasi makromolekul seperti lemak dan gugus tiol pada protein dan mengganggu homeostasis kalsium akibat menurunnya GSH (gugus tiol) ${ }^{8}$. Peningkatan radikal bebas ditandai dengan kenaikan kadar MDA( Malondialdehid). 
Dengan melakukan Uji Normalitas Kolmogorov-Smirnov dengan menggunakan SPSS version 20,0 dengan taraf signifikansi $(\alpha)=0,05$, maka didapatkan data pengukuran kadar SGOT, SGPT dan MDA dikatakan mempunyai distribusi normal karena nilai $\mathrm{p}>\alpha^{9}$.

Selanjutnya dengan uji Paired Samples T-Test menggunakan SPSS version 20,0 yang membandingkan pengaruh 3 dosis ekstrak daun kelor terhadap kelompok kontrol positif maupun kelompok kontrol negatif terhadap kadar SGOT, maka didapatkan hasil bahwa dosis tinggi yaitu dosis C (1gr/200BB) dapat menurunkan kadar SGOT secara signifikan jika dibandingkan dengan kelompok kontrol negatif karena nilai $\mathrm{p}$-value $=0,016$ dan nilai ini berarti lebih kecil dari $\alpha(0,05)$, sedangkan kelompok dosis A dengan pvalue $=0,126$ dan $\mathrm{B}$ dengan $\mathrm{p}$ - value $=0,239$ tidak memberikan pengaruh yang signifikan sekalipun secara kasat mata ada penurunan kadar SGOT dibandingkan dengan kelompok kontrol. Dengan Uji yang sama untuk pengaruh dosis parasetamol dosis toksis juga memberikan pengaruh adanya kenaikan kadar SGOT pada kelompok kontrol negatif jika dibandingkan dengan kelompok kontrol positif karena nilai p-value $=0.007$ yang berarti $<\alpha(0,05)$.
Untuk kadar SGPT, dengan uji Paired Samples T-Test menggunakan SPSS version 20,0 yang membandingkan pengaruh 3 dosis ekstrak daun kelor terhadap kelompok kontrol positif maupun kelompok kontrol negatif terhadap kadar SGPT, maka didapatkan hasil bahwa dosis tinggi yaitu dosis C (1gr/200BB) dapat menurunkan kadar SGPT secara signifikan jika dibandingkan dengan kelompok kontrol negatif karena nilai $\mathrm{p}$-value $=0,009$ dan nilai ini berarti lebih kecil dari $\alpha(0,05)$, sedangkan kelompok dosis A dengan pvalue $=0,133$ dan $\mathrm{B}$ dengan $\mathrm{p}$ - value $=0,206$ tidak memberikan pengaruh yang signifikan sekalipun secara kasat mata ada penurunan kadar SGPT dibandingkan dengan kelompok kontrol. Dengan Uji yang sama untuk pengaruh dosis parasetamol dosis toksis juga memberikan pengaruh adanya kenaikan kadar SGPT pada kelompok kontrol negatif jika dibandingkan dengan kelompok kontrol positif karena nilai p-value $=0.037$ yang berarti $<\alpha(0,05)$, yang berarti bahwa dengan dosis toksik parasetamol dapat meningkatkan kadar SGOT maupun SGPT pada kelompok kontrol negatif dan dengan pemberian ekstrak daun kelor ternyata yang dapat menurunkan kadar SGOT dan SGPT secara efektif adalah kadar 1gr/200BB tikus. Semua hasil kadar SGPT dan SGOT disajikan pada Gambar 1 sebagai berikut: 


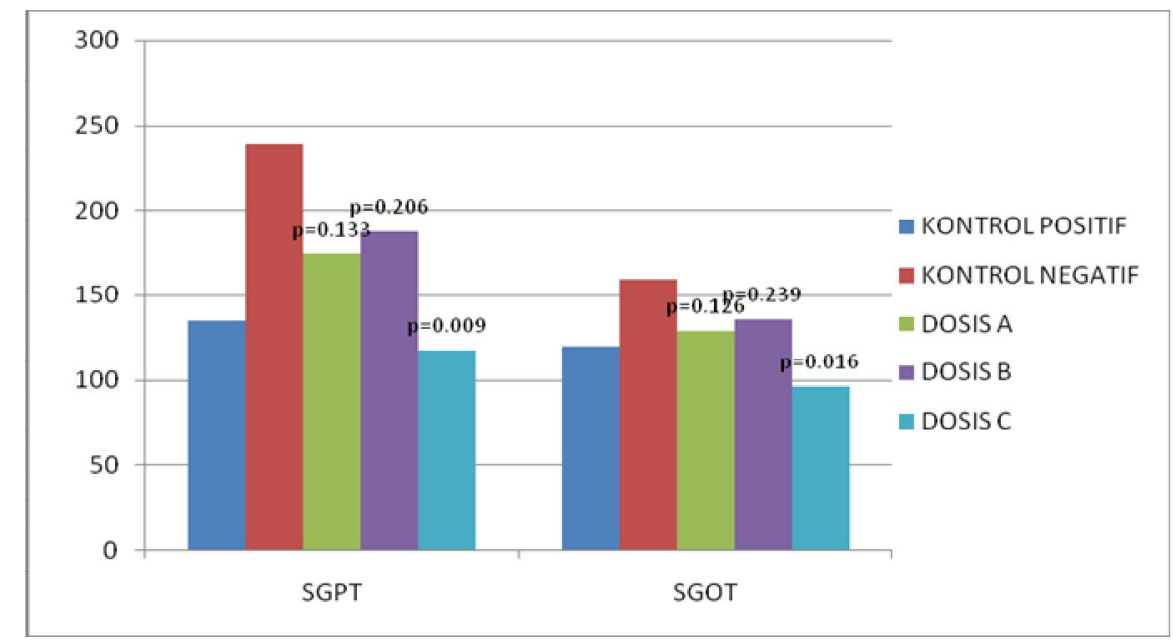

Gambar 1. Grafik Hubungan antara Pemberian Dosis Ekstrak Daun Kelor (Moringa Oleifera) dengan kadar SGPT dan SGOT dengan nilai $p$-value pada uji Paired Sample T-Test.

Berdasarkan penelitian Logu (2005), menyatakan bahwa daun Kelor mempunyai kandungan vitamin C $120 \mathrm{mg}$ dalam 100 gr pada bagian daunnya, bahan yang terkandung mempunyai aktifitas antioksidan yang sangat kuat ${ }^{10}$.Daun Kelor juga mengandung alkaloids, saponins, fitosterol, tannin,fenolik dan flavonoid yang juga mempunyai aktifitas antioksidan $^{11}$.Aktifitas antioksidatif flavonoid pada daun Kelor bersumber pada kemampuan mendonasikan atom hidrogennya atau melalui kemampuan mengkelat logam ${ }^{12}$.

Untuk kadar MDA, dengan uji Paired Samples T-Test menggunakan SPSS version 20,0 yang membandingkan pengaruh 3 dosis ekstrak daun kelor terhadap kelompok kontrol negatif terhadap kadar MDA, maka didapatkan hasil bahwa dosis rendah $(\mathrm{A}=0,25$ gr/200BB)), dosis sedang $(\mathrm{B}=0,50 \mathrm{gr} / 200 \mathrm{BB}))$ dan dosis tinggi yaitu dosis C (1gr/200BB) dapat menurunkan kadar MDA secara signifikan jika dibandingkan dengan kelompok kontrol negatif karena nilai p-value masing-masing sebesar 0,05, 0,01 dan 0,001 dan nilai ini berarti lebih kecil dari $\alpha(0,05)$, yang berarti ada penurunan kadar MDA dibandingkan dengan kelompok kontrol negatif. Dengan Uji yang sama untuk pengaruh dosis parasetamol dosis toksis juga memberikan pengaruh adanya kenaikan kadar MDA pada kelompok kontrol negatif jika dibandingkan dengan kelompok kontrol positif karena nilai pvalue $=0.006$ yang berarti $<\alpha(0,05)$, yang berarti bahwa dengan dosis toksik parasetamol dapat meningkatkan kadar MDA pada kelompok kontrol negatif dan dengan pemberian ekstrak daun kelor ternyata yang dapat menurunkan kadar MDA yang paling efektif adalah kadar 1gr/200BB tikus. Hal ini berarti bahwa kandungan flavonoid pada ekstrak daun kelor dapat berpotensi sebagai antioksidan sekaligus sebagai hepatoprotektor pada dosis 1gr/200grBB tikus. Berikut hasil pemberian dosis ekstrak Daun Kelor dengan kadar MDA disajikan pada Gambar 2 . 


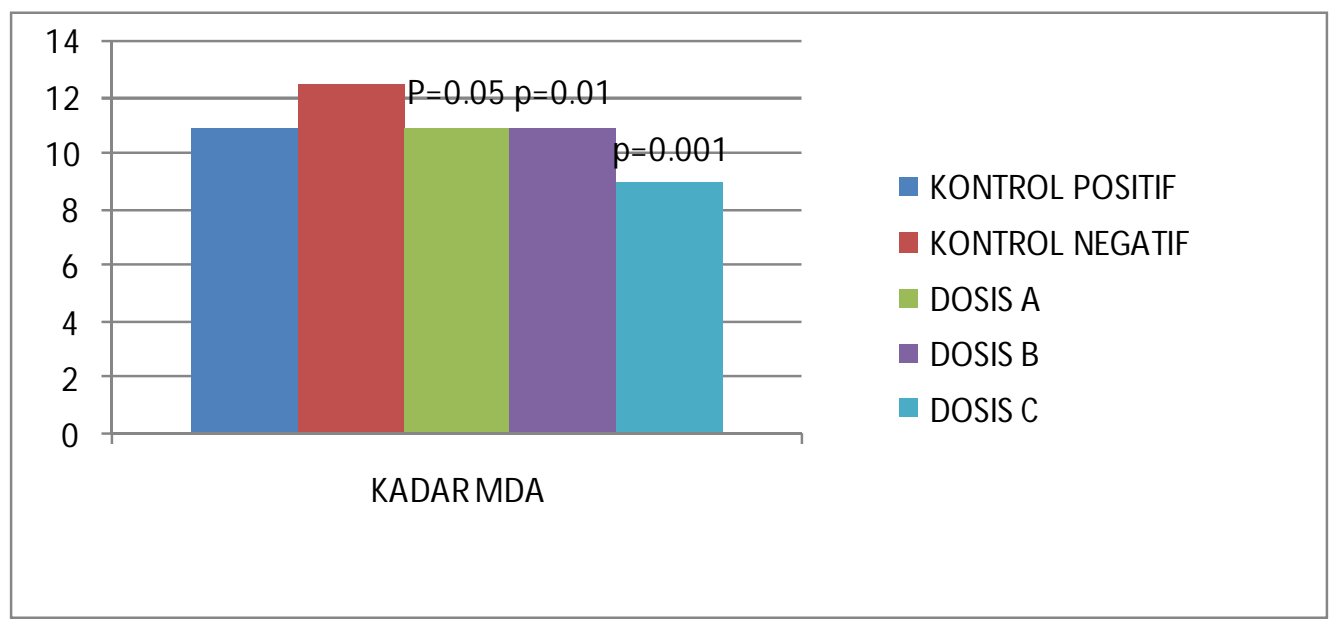

Gambar 2. Grafik Pemberian dosis Ekstrak Daun Kelor (Moringa

Oleifera) dengan Kadar MDA.

\section{KESIMPULAN}

Berdasarkan penelitian yang telah dilakukan, maka dapat disimpulkan bahwa:

1. Ekstrak Daun Kelor dapat berpotensi sebagai antioksidan dengan bukti bahwa dapat menurunkan kadar MDA pada tikus yang diinduksi dengan parasetamol dosis toksis

2. Ekstrak daun Kelor dapat berpotensi sebagai hepatoprotektor dengan bukti bahwa dapat menurunkan kadar SGOT dan SGPT pada tikus yang diinduksi dengan parasetamol dosis toksis.

3. Dosis yang paling efektif Ekstrak Daun Kelor yang dapat menurunkan kadar SGOT, SGPT maupun kadar MDA adalah dosis $1 \mathrm{gr} / 200 \mathrm{grBB}$ tikus.

\section{SARAN}

Berdasarkan hasil penelitian ini,maka disarankan:

1. Mengidentifikasi lebih lanjut gambaran histopatologi hepar dari tikus yang diinduksi dengan parasetamol dosis toksik

2. Membuat variasi dosis toksik dan variasi waktu untuk menguji efek toksisitas, efek antioksidan dan hepatoprotektor dari parasetamol terhadap dosis ekstrak daun kelor.

\section{UCAPAN TERIMAKASIH}

Kami mengucapkan terimakasih sebesarbesarnya kepada Dirjen DIKTI yang telah memberikan dana pada penelitian hibah pemula ini.

\section{DAFTAR PUSTAKA}

1. Zullies, I., 2010.Cerdas Mengenali Obat. Yogyakarta.Kanisiuss.

2. Koh, D dan Jeratnam, 2009, Buku Ajar dan Praktik Kedokteran Kerja, Jakarta:EGC.

3. Ramatina.2011. Efektifitas Berbagai Suplemen Antioksidan Terhadap Penurunan Status Oksidatif Malondialdehyd (MDA Plasma) Pada Mahasiswa Alih jenis Ipb. Skripsi. Institut Pertanian Bogor. Bogor

4. Bobilya, D.J., Heim, K.E., Tagliaferro, A.R., 2002, Flavonoid Antioxidants: Chemistry, Metabolismand Structure activity Relationship, Journal of Nutritional Biochemistry, 13:572-584

5. Caceres,A. Saravia,A.et al. 1992. Pharmacologic Properties of Moringa Oleifera. 2: Screening for Antispasmodik, antiinflamatory and Diuretic Activity, J Ethnopharmacol. 36:233-237

6. Bukar, A., Uba,A. And Oyeyi, T.I. 2010. Antimicrobial Profile of 
Moringa oleifera Lan. Extracts Agains Some Food-Bornr Microorganisms. Bayero Journalof Pure and Applied Sciences, 3(1): 43 48.

7. Hastuti, T, 2008, Aktifitas Enzim Transaminase dan Gambaran Histopatologi Hati Tikus yang diberi Kelapa Kopyor Pasca Induksi Parasetamol.

8. Murugesh, K.S., et al, 2005, Hepatoprotective and antioxidant role of Berbens Tinctona Lasch Leaves on Parasetamol induced Hepatic Damage in Rats, Iranian, J. Pharmacol Therapeutic (IJPT) 4(1): 64-69
9. Santoso, S., 2005, Mengatasi Berbagai Masalah Statistik dengan SPSS versi 11,5, Penerbit PT. ELEX media Komputindo Kelompok Gramedia, Jakarta

10. Logu, T, Electrophoresis in Gels. Dalam Jan ChisterJanson\& Lary R., 2005, Protein Purification: Principles, High Resolution Methods, and Applications ( $2^{\text {nd }}$ ed),p: 464-469, New York.

11. Rajanandh, M.G, et.al., 2012, Moringa Oleifera A Herbal Medicine for Hyperlipidemia: A Pre Clinical Report, Department of Pharmacology J.S.S. Tamil, Nadu, India.

12. Redha, A., 2010, Flavonoid: Struktur, Sifat Antioksidatif dan Peranannya dalam Sistem Biologis, Jurnal Belian vol 9, p:196-202

\section{Reviewer}

dr. Pratika Yuhyi Hernanda, M.Sc., Ph.D. 